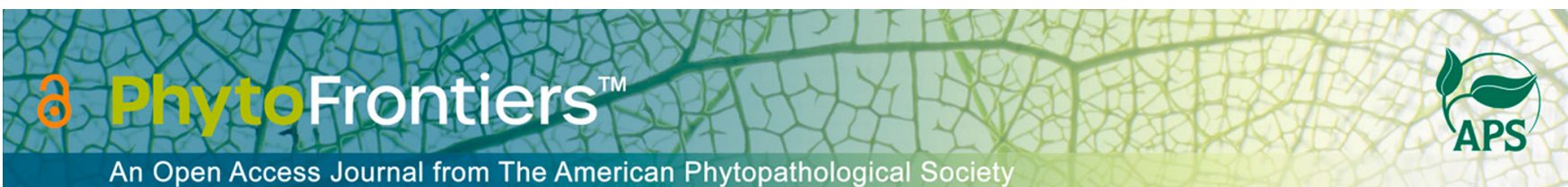

\title{
Research
}

\section{Field Studies on the Effect of Rye Cover Crop on Soybean Root Disease and Productivity}

\author{
Grazieli Araldi-Da-Silva ${ }^{1}$ | Yuba R. Kandel ${ }^{1}$ (i) | Gang Han $^{1}$ | Daren S. Mueller ${ }^{1}$ | Matthew J. Helmers ${ }^{2}$ | \\ Thomas C. Kaspar ${ }^{3}$ | Leonor F. S. Leandro ${ }^{1+}{ }^{+}$(D) |
}

${ }^{1}$ Department of Plant Pathology and Microbiology, lowa State University, Ames, IA 50011

2 Department of Agricultural and Biosystems Engineering, lowa State University, Ames, IA 50011

3 USDA-ARS National Soil Tilth Laboratory, Ames, IA 50011

† Corresponding author: L. F. S. Leandro; lleandro@iastate.edu

Accepted for publication 8 December 2021.

\section{Funding}

This research was partially funded by the soybean checkoff through the lowa Soybean Association and was part of a regional collaborative project supported by the United States Department of Agriculture-National Institute of Food and Agriculture (USDA-NIFA), Award No. 2011-68002-30190, “Cropping systems coordinated agricultural project (CAP): Climate change, mitigation, and adaptation in corn-based cropping systems"; Coordenação de Aperfeiçoamento de Pessoal de Nível Superior Brasil (CAPES) (grant number 99999.002095/2015-07)

The author(s) declare no conflict of interest.

\begin{abstract}
Cover crops improve soil and water quality in annual cropping systems, but knowledge of their impact on soybean (Glycine max L.) seedling and root diseases is limited. The effects of winter rye cover crops (Secale cereale L.) on soybean population, biomass, root morphology, seedling and root diseases, pathogen incidence, canopy reflectance, and yield were assessed over 2 years in lowa and Missouri, U.S.A. Plots without a rye cover crop were compared with plots with early-kill rye and late-kill rye cover crops, which were terminated 34 to 49 days or 5 to 17 days before soybean planting, respectively. Soybean shoot dry weight, root rot severity, and incidence of Fusarium spp. and Pythium spp. on roots were not influenced by the treatments. Soybean grain yield and plant population were reduced in the presence of rye in 2 site years, increased in 1 site year, and unchanged in the remaining site years. Soybean canopy reflectance was measured at $810 \mathrm{~nm}$, and measurements were first made at 70 to 80 days after planting (DAP). At least five measurements were obtained at 7- to 15-day intervals, ending at 120 to 125 DAP. Measurements at approximately 120 to 125 DAP differed by treatments but were not consistently associated with the presence or absence of a rye cover crop. Our field studies suggest that lowa and Missouri soybean farmers can use winter rye as a cover crop in soybean fields with low seedling disease pressure without increasing the risk of seedling and root diseases or suppressing yield.
\end{abstract}

Keywords: disease incidence, Fusarium spp., Pythium spp., root rot severity, soybean yield

The United States is the world's leading producer of corn (Zea mays L.) and soybean (Glycine max L.), which are grown primarily in Midwestern states (FAOSTAT 2018). In a typical corn-soybean rotation in this region, living crop plants are only present for 4 to 6 months of the year, with the soil surface remaining fallow for the other 6 to 8 months 
(Kaspar and Singer 2011). In these systems, there is a high risk of soil erosion (Pimentel et al. 1995) and loss of nutrients and organic matter (Burkart and James 1999; David and Gentry 2000). In the Midwest, the U.S. Environmental Protection Agency (EPA) has requested that states develop plans to reduce the amount of nitrogen and phosphorus lost from agricultural fields that then is transported to the Gulf of Mexico via the Mississippi River (EPA 2008).

One approach to addressing these problems is to incorporate winter cover crops into corn and soybean cropping systems because they can improve or maintain soil health and protect water quality by reducing soil erosion and nutrient loss (Kaspar et al. 2007; Kaspar and Singer 2011; Lu et al. 2000; Qi and Helmers 2010; Sarrantonio and Gallandt 2003). Additionally, soils that are cultivated to cover crops in a corn-soybean rotation have higher indicators of soil health — such as organic matter, potential nitrogen mineralization, particulate organic matter, plant available water, and earthworm numbers - than soils without cover crops in the rotation (Basche et al. 2016; Korucu et al. 2018; Moore et al. 2014; Villamil et al. 2006).

In the Midwestern United States, cover crops are usually planted shortly before or soon after the cash crop is harvested in the fall and terminated (by winter temperatures or herbicide application) before or immediately after planting the next cash crop the following spring (Sarrantonio and Gallandt 2003). The number of cover crop species that can be planted in the upper Midwest in this window of the corn-soybean rotation is limited by cold temperatures and short days during winter; only the most winter-hardy species can establish and survive. Winter cereal rye (Secale cereale L.) is the predominant cover crop planted in the region because it can overwinter and produce enough biomass to provide benefits to the agroecosystem (Kaspar and Bakker 2015; Snapp et al. 2002).

Cover crops also have the potential to impact soil health by altering microbial populations and ecology. They can increase populations of mycorrhizal fungi, which are often used as an indicator of soil health (Galvez et al. 1995; Lehman et al. 2012). Cover crops also have the potential to suppress soilborne diseases of grain crops (Van Os and Van Ginkel 2001) by increasing activity and diversity of soil microorganisms that can compete with plant pathogens for nutrients, favoring the presence of antagonists against specific plant pathogens, or releasing compounds that inhibit plant pathogens (Bonanomi et al. 2007; Nitta 1991; Rothrock et al. 1995; Van Os and Van Ginkel 2001). For instance, adding a winter rye cover crop following a canola or rapeseed (Brassica napus L.) rotation reduced black scurf caused by Rhizoctonia solani and common scab caused by Streptomyces scabiei in a subsequent potato crop (Solanum tuberosum L.) (Larkin et al. 2010), and a rye cover crop reduced Verticillium wilt caused by Verticillium dahliae in a subsequent potato crop (Davis et al. 2010).

Cover crops can also enhance populations of organisms that are pathogenic to the subsequent cash crop, especially if the cover crop is a host for that particular pathogen. Rothrock et al. (1995) showed that R. solani was isolated more frequently from seedlings of cotton (Gossypium hirsutum L.) after incorporation of a cover crop of hairy vetch (Vicia villosa) than from seedlings after a winter fallow period. They also observed an increase in $R$. solani and Pythium spp. populations in soil and a reduction in cotton stand after a cover crop of hairy vetch, possibly due to infection of cotton by $R$. solani. In another study, Bakker et al. (2016) showed that cereal rye is host to many of the same pathogens that cause root disease in seedlings of corn and can reduce corn yield. The pathogens recovered by Bakker et al. (2016) from rye included Fusarium graminearum, F. oxysporum,
P. sylvaticum, and P. torulosum. These same organisms can also cause diseases in seedlings and root rot in soybean (Arias et al. 2013a, b; Broders et al. 2007; Ellis et al. 2011) and could contribute to reduced yields (Allen et al. 2017). It is therefore possible that cover crops could also create a risk to soybean health and productivity.

Although the potential benefits of cover crops have motivated some Midwestern farmers to incorporate them into the cornsoybean rotation system, the acreage planted to cover crops is small (Singer et al. 2007). In 2017, 3.5\% of Midwestern farm ground was planted to cover crops (USDA-NASS 2019). The use of cover crops is constrained by complex issues, including costs of establishment and terminating the crops, limited favorable growing periods between harvesting and planting cash crops (Sarrantonio and Gallandt 2003), risk of delaying cash-crop planting (Arbuckle and Roesch-McNally 2015), and changes in current farming practices (Kaspar and Singer 2011). Additionally, the potential for undesirable factors such as an increase in the density of soilborne pathogens (Bakker et al. 2016), greater risk of diseases (Acharya et al. 2017; Rothrock et al. 1995), and possible yield reductions (Eckert 1988; Kaspar and Bakker 2015; Liebl et al. 1992; Reddy 2001) can also discourage adoption.

Although winter rye cover crops are often grown preceding soybean production in the upper Midwest, there is limited information on the effects of winter rye cover crops on soybean seedling and root diseases. Bakker et al. (2016) isolated soybean pathogens from rye roots; thus, it is possible that rye could be a source of inoculum for soybean root diseases. This would create an additional challenge for farmers who plant a rye cover before soybeans. However, Acharya et al. (2020) reported no consistent negative effect of winter rye on soybean growth, root rot, and yield in an experiment conducted at one location in central Iowa. It is important to determine if there are detrimental effects of rye on soybean crops so that farmers can anticipate the problem and utilize appropriate cover crop management practices to minimize the risks. Our study aimed to assess the influence of winter cereal rye cover crops on soybean seedling and root diseases, growth parameters, and grain yield.

\section{MATERIALS AND METHODS}

\section{Field experiments}

The effects of winter cereal rye cover crops on subsequent soybean crops were assessed in four naturally pathogen-infested fields during 2012-2013 and 2015-2016 (8 site years) (Table 1). In 2012-2013, trials were conducted at the Agriculture Drainage Water Research Site (ADW) in Gilmore City, Iowa, and at the Bradford Research and Extension Center (BREC) in Columbia, Missouri. In 2015-2016, trials were conducted at two university research farms located in Boone County, Iowa: Boyd Farm and Iowa State University Agronomy Farm (ISUAG). Soil type, plot size, and number of replicates differed at each location (Table 1). All sites were managed using a long-term, no-till corn-soybean rotation. At each location, treatments included a fall-planted, winter rye cover crop and a no-cover crop treatment. Rye was terminated by glyphosate herbicide application 34 to 49 days before soybean planting (early-kill rye) or 5 to 17 days before planting soybean (late-kill rye) (Table 2).

Field experiments were designed in a randomized complete block design with four to five replications. The treatments used at $\mathrm{ADW}$ and Boyd were no rye and late-kill rye; at BREC, the treatments were no rye and early-kill rye; and at ISUAG, the treatments used were no rye, early-kill rye, and late-kill rye 
(Table 1). The planting date for rye and soybean, rye and soybean seed rate, rye termination date, soybean planting date, rye and soybean seed rates, and soybean cultivars varied at each location (Table 2). Precipitation data for each field were collected at the weather station closest to each location (Table 3 ).

\section{Plant population and plant height}

Soybean plant population was determined at the V2 growth stage (Fehr et al. 1971). At ADW and BREC, all plants were counted in the two center rows in each plot. At Boyd and ISUAG, plants were counted in nine and eight, respectively, 1-m-long sections evenly distributed in each plot. Data were converted to plants/hectare prior to analysis.

Plant height was measured as the length of the main stem from the soil level to the tip of the stem apex at vegetative (V2 to V5) growth stage (Fehr et al. 1971). A total of 36 and 32 arbitrarily selected plants per plot were measured at Boyd and ISUAG, respectively. Plant height was not recorded at ADW and BREC.

\section{Soybean root rot incidence and severity}

Plants were sampled during the V2 to V5 growth stage for estimating root rot incidence and severity. Two to three adjacent plants were sampled from 8 to 10 evenly spaced locations within the plot, avoiding the two outermost rows, for a total of 27 plants per plot at Boyd, 16 at ISUAG, and 30 at ADW and BREC. Roots were excavated gently by using a spade at a distance of approximately $10 \mathrm{~cm}$ away from the plant and at least $15 \mathrm{~cm}$ deep; soil attached to the roots was removed by gently shaking the root system, and plants were placed in plastic bags and transported in coolers containing ice packs. In the greenhouse, shoots were separated from the roots at a point $3 \mathrm{~mm}$ above the first lateral root. Roots were then rinsed under running tap water and visually assessed for external symptoms of root rot. Root rot severity was recorded as the estimated percentage of total root area with brown to black discoloration ([brown to black discolored area $\div$ total root area] $\times 100$ ), where zero indicates absence of disease. Root rot incidence was expressed as the percentage of seedling root systems with root rot severity greater than 10\% ([number of root samples with root rot severity $>10 \% \div$ total number of root samples] $\times 100$ ). One rater was responsible for all visual disease assessments.

Symptomatic soybean root pieces were plated to detect the presence of Pythium spp. or Fusarium spp. Root pieces were taken from all roots used for visual root rot ratings. To detect the presence of Pythium, four symptomatic root pieces $(\sim 1 \mathrm{~cm}$ long) were excised from each root, rinsed twice in sterile distilled water, cleaned with a paintbrush to remove soil particles, and then blotted dry on sterile paper towels. Root pieces were plated on PARP + B medium, which is semi-selective for oomycetes (Jeffers and Martin 1986; $0.05 \mathrm{~g}$ of pimaricin, $0.25 \mathrm{~g}$ of ampicillin, $0.01 \mathrm{~g}$ of rifampicin, $0.1 \mathrm{~g}$ of pentachloronitrobenzene [PCNB], $0.01 \mathrm{~g}$ of benomyl, $17 \mathrm{~g}$ of corn meal agar, and 1 liter of water). For Fusarium detection, four symptomatic root pieces $(\sim 1 \mathrm{~cm}$ long) were surface disinfested for $2 \mathrm{~min}$ in $0.5 \%$ sodium hypochlorite, rinsed twice in tap water, blotted dry on sterile paper towels, and plated on Fusarium semi-selective media. In 2015, Komada medium (Komada 1975) was used because it is selective for F. oxysporum, (Komada 1975; $20 \mathrm{~g}$ of agar, $15 \mathrm{~g}$ of D-galactose, 2 $\mathrm{g}$ of L-asparagine, $1 \mathrm{~g}$ of $\mathrm{K}_{2} \mathrm{HPO}_{4}, 0.5 \mathrm{~g}$ of $\mathrm{KCl}, 0.5 \mathrm{~g}$ of $\mathrm{MgSO}_{4} \bullet$ $7 \mathrm{H}_{2} \mathrm{O}, 0.01 \mathrm{~g}$ of Fe-Na-EDTA, $0.3 \mathrm{~g}$ of streptomycin sulfate, $1 \mathrm{~g}$ of $\mathrm{Na}_{2} \mathrm{~B}_{4} \mathrm{O}_{7} \bullet 10 \mathrm{H}_{2} \mathrm{O}, 0.5 \mathrm{~g}$ of Oxgall, $0.75 \mathrm{~g}$ of PCNB, and 1 liter of water). In 2016, roots were plated on modified Nash Snyder medium (MNSM; $20 \mathrm{~g}$ of agar, $15 \mathrm{~g}$ of peptone, $1 \mathrm{~g}$ of $\mathrm{KH}_{2} \mathrm{PO}_{4}$,

\section{TABLE 1}

Summary of site characteristics and treatments at Gilmore (Agriculture Drainage Water Research Site [ADW]) and the Bradford Research and Extension Center (BREC) from 2012 to 2013, and from Boyd Farm and Iowa State University Agronomy Farm (ISUAG) from 2015 to 2016

\begin{tabular}{|c|c|c|c|c|c|}
\hline Site & Location & Geographical coordinates & Soil & Plot size (ha) & Treatments \\
\hline ADW & Gilmore City, IA, Pocahontas Co. & $42^{\circ} 74^{\prime} 77^{\prime \prime} \mathrm{N}, 94^{\circ} 49^{\prime} 52^{\prime \prime} \mathrm{W}$ & Nicollet, Webster, Canisteo & 0.0580 & No rye; Late-kill rye \\
\hline BREC & Columbia, MO, Boone Co. & $38^{\circ} 90^{\prime} 42^{\prime \prime} \mathrm{N}, 92^{\circ} 20^{\prime} 89^{\prime \prime} \mathrm{W}$ & Leonard, Mexico & 0.0044 & No rye; Early-kill rye \\
\hline Boyd & Boone Co., IA & $42^{\circ} 0^{\prime} 29^{\prime \prime} \mathrm{N}, 93^{\circ} 47^{\prime} 31^{\prime \prime} \mathrm{W}$ & Clarion, Nicollet & 0.0207 & No rye; Late-kill rye \\
\hline ISUAG & Boone Co., IA & $42^{\circ} 01^{\prime} 17^{\prime \prime} \mathrm{N}, 93^{\circ} 45^{\prime} 34^{\prime \prime} \mathrm{W}$ & Clarion, Nicollet, Webster & 0.0093 & $\begin{array}{l}\text { No rye; Early-kill rye; } \\
\text { Late-kill rye }\end{array}$ \\
\hline
\end{tabular}

\section{TABLE 2}

Rye termination dates, rye seed rate, soybean cultivars, soybean planting dates, and soybean seed rate at Gilmore (Agriculture Drainage Water Research Site [ADW]) and the Bradford Research and Extension Center (BREC) from 2012 to 2013, and Boyd Farm and Iowa State University Agronomy Farm (ISUAG) from 2015 to 2016

\begin{tabular}{|c|c|c|c|c|c|c|}
\hline \multirow[b]{2}{*}{ Year, site } & \multicolumn{3}{|c|}{ Rye } & \multicolumn{3}{|c|}{ Soybean } \\
\hline & Early kill date ${ }^{a}$ & Late kill date & Seed rate $(\mathrm{kg} / \mathrm{ha})$ & Cultivar & Planting date & Seed rate (seeds/ha) \\
\hline \multicolumn{7}{|l|}{2012} \\
\hline ADW & NA & 9 May & 237 & P92Y53 & 16 May & 355,000 \\
\hline BREC & 11 April & NA & 148 & $\operatorname{Ag} 3803$ & 15 May & 395,000 \\
\hline \multicolumn{7}{|l|}{2013} \\
\hline ADW & NA & 23 May & 237 & P92Y53 & 6 June & 355,000 \\
\hline BREC & 20 April & NA & 148 & P94Y01 & 8 June & 395,000 \\
\hline \multicolumn{7}{|l|}{2015} \\
\hline Boyd & NA & 30 April & 63 & P19T01R & 4 May & 395,000 \\
\hline ISUAG & 16 April & 5 May & 63 & Ag2136 & 19 May & 346,000 \\
\hline \multicolumn{7}{|l|}{2016} \\
\hline Boyd & NA & 25 April & 63 & P19T01R & 6 May & 395,000 \\
\hline ISUAG & 19 April & 16 May & 63 & $\operatorname{Ag} 2136$ & 2 June & 346,000 \\
\hline
\end{tabular}

${ }^{a} \mathrm{NA}=$ Not available, treatment was not included in the trial. 
$0.5 \mathrm{~g}$ of $\mathrm{MgSO}_{4} \cdot 7 \mathrm{H}_{2} \mathrm{O}, 0.75 \mathrm{~g}$ of PCNB, $0.3 \mathrm{~g}$ of streptomycin sulfate, $0.12 \mathrm{~g}$ of neomycin sulfate, and 1 liter of water) (Rupe et al. 1997). Nash Snyder medium is semi-selective for multiple species of Fusarium.

Plates were incubated at room temperature $\left(23 \pm 2^{\circ} \mathrm{C}\right)$. Plates containing selective media for Pythium were incubated in the dark for 4 days, and plates with media for Fusarium were incubated under constant fluorescent light for 15 days. Isolates growing on the plates were examined under an optical microscope (AmScope $40 \times$ to $1,000 \times$, Irvine, CA, U.S.A.) to confirm the presence of the pathogens of interest. Fusarium and Pythium spp. were identified to the genus level based on morphological characteristics (Nelson et al. 1983; Van der Plaats-Niterink 1981). Putative Fusarium and Pythium cultures, respectively, were transferred onto 1/3-strength potato dextrose agar and dilute V8 agar (Pitt and Miller 1968; $40 \mathrm{ml}$ of V8 juice, $0.6 \mathrm{~g}$ of $\mathrm{CaCO}_{3}, 0.2 \mathrm{~g}$ of yeast extract, $1.0 \mathrm{~g}$ of sucrose, $0.01 \mathrm{~g}$ of cholesterol, $20 \mathrm{~g}$ of agar, and 1 liter of water). The incidence (\%) of Fusarium spp. and Pythium spp. in plated root pieces was estimated as the number of roots with pathogen presence divided by the total root samples per treatment times 100. Isolated organisms that were not Fusarium spp. or Pythium spp. were not evaluated in this study.

\section{Soybean root characteristics and root and shoot weight}

Digital images of a subset of soybean roots (15 root systems from ADW and BREC, 10 from Boyd, and 8 from ISUAG) were obtained by scanning roots on a flatbed scanner (Epson Perfection V700 Photo Scanner, Epson America, Long Beach, CA, U.S.A.). Root scans were not obtained for samples from ADW and BREC in 2012. Image analysis was conducted with the WinRhizo 2008 software (Regent Instrument, Québec City, Québec, CAN) to esti- mate root length, surface area, volume, and diameter and number of tips, crossings, and forks for each soybean root.

Shoot and root dry weight were assessed using the plants previously evaluated for root rot incidence and severity. Each soybean shoot and root system was placed in a paper bag, including the root pieces left from the root isolations, dried at 60 to $75^{\circ} \mathrm{C}$ for 24 to $48 \mathrm{~h}$ in a forced-air oven, and then weighed. Root and shoot weight were not recorded at ADW and BREC.

\section{Canopy reflectance}

The percentage of sunlight reflected by soybean canopies at Boyd Farm was evaluated in 2015 and 2016 and at ISUAG only in 2016. Canopy reflectance was obtained using a handheld multispectral radiometer (CROPSCAN, Rochester, MN). Assessments were first made at 70 to 80 days after planting (DAP), and at least five measurements were obtained at 7- to 15-day intervals, ending at 120 to 125 DAP. The radiometer was positioned over the same section of the canopy at each assessment time. At Boyd Farm, assessments were made at five arbitrarily selected points in each of the three center rows, for a total of 15 points in each plot. At ISUAG, reflectance was assessed at two points arbitrarily selected in each of the four center rows, totaling eight points per plot. Incident and reflected radiation from soybean canopies were measured in the $810-\mathrm{nm}$ wavelength band because this nearinfrared region has been shown to have the best agreement with green leaf area index (GLAI), pathogen stress, and yield in other studies (Guan et al. 2001; Nutter et al. 2002). Reflectance assessments were conducted on a clear day between 1100 and 1500 Central Standard Time (CST), when soybean canopies were dry (Green et al. 1998; Guan et al. 2001).

\section{TABLE 3}

Monthly precipitation for May through September observed at Gilmore (Agriculture Drainage Water Research Site [ADW]) and the Bradford Research and Extension Center (BREC) in 2012 and 2013, and at Boyd Farm and Iowa State University Agronomy Farm (ISUAG) in 2015 and 2016

\begin{tabular}{|c|c|c|c|c|c|c|c|}
\hline \multirow[b]{2}{*}{ Field site, year ${ }^{\mathrm{a}}$} & \multirow[b]{2}{*}{ Station } & \multicolumn{5}{|c|}{ Precipitation (mm) } & \multirow[b]{2}{*}{ Total (mm) } \\
\hline & & May & June & July & August & September & \\
\hline ADW & IA6719 Pocahontas & & & & & & \\
\hline 2012 & & 82 & 66 & 28 & 22 & 77 & 275 \\
\hline 2013 & & 236 & 134 & 26 & 33 & 20 & 450 \\
\hline BREC & MO1791 Columbia & & & & & & \\
\hline 2012 & & 25 & 39 & 18 & 49 & 46 & 177 \\
\hline 2013 & & 265 & 47 & 41 & 45 & 43 & 441 \\
\hline Boyd and ISUAG & IA 0200 AMES-8-WSW & & & & & & \\
\hline 2015 & & 114 & 175 & 151 & 208 & 128 & 778 \\
\hline 2016 & & 112 & 34 & 200 & 104 & 188 & 640 \\
\hline
\end{tabular}

a Boyd and ISUAG had the same weather station.

\section{TABLE 4}

Mean soybean shoot and root dry weight (mean \pm standard error) at V2-V5 for the no rye, early-kill rye, and late-kill rye treatments at Boyd Farm and Iowa State University Agronomy Farm (ISUAG) in 2015 and 2016

\begin{tabular}{|c|c|c|c|c|c|c|}
\hline \multirow[b]{2}{*}{ Field site, year } & \multicolumn{3}{|c|}{ Shoot dry weight (g) } & \multicolumn{3}{|c|}{ Root dry weight (g) } \\
\hline & No rye & Early-kill rye ${ }^{a}$ & Late-kill rye ${ }^{\mathrm{b}}$ & No rye & Early-kill rye & Late-kill rye \\
\hline \multicolumn{7}{|l|}{ Boyd } \\
\hline 2015 & $0.49 \pm 0.02$ & NA & $0.46 \pm 0.02$ & $0.15 \pm 0.01$ & NA & $0.15 \pm 0.00$ \\
\hline 2016 & $1.87 \pm 0.14$ & NA & $1.30 \pm 0.10$ & $0.57 \pm 0.04$ & NA & $0.40 \pm 0.03$ \\
\hline \multicolumn{7}{|l|}{ ISUAG } \\
\hline 2015 & $0.91 \pm 0.08$ & $1.08 \pm 0.08$ & $1.09 \pm 0.08$ & $0.21 \pm 0.02$ & $0.23 \pm 0.02$ & $0.19 \pm 0.01$ \\
\hline 2016 & $2.04 \pm 0.04$ & $1.86 \pm 0.04$ & $1.96 \pm 0.30$ & $0.33 \pm 0.01$ & $0.28 \pm 0.02$ & $0.30 \pm 0.02$ \\
\hline
\end{tabular}

${ }^{a}$ Early-kill rye, rye terminated at 34 to 49 days before soybean planting. NA $=$ Not available, the treatment was not included in the trial.

${ }^{\mathrm{b}}$ Late-kill rye, rye terminated at 5 to 17 days before soybean planting. 


\section{Soybean grain yield}

Plots were mechanically harvested at crop maturity with a small-plot combine. Yield data were adjusted to $13 \%$ moisture and converted to metric tons/hectare.

\section{Statistical analysis}

Analysis of variance (ANOVA) was performed in SAS (version 9.4; Statistical Analysis Systems Institute, Cary, NC, U.S.A.), using a mixed-model PROC GLIMMIX for all measured variables. Data were analyzed in two ways: (i) pooled across the site years and (ii) individually. Site years were combined for root rot severity, root rot incidence, pathogen incidence, root morphology, shoot dry weight, and plant height, which were, with rye cover crop treatment, classified as a fixed factor, and site year and block (nested within site year) were treated as random factors, because initial analyses revealed no significant or biologically meaningful interactions between site year and rye treatment effects. For pooled analysis, rye crop treatment was considered a fixed-effect factor, and site year and block nested within site year were considered random factors. Data for plant population, root dry weight, canopy reflectance, and grain yield were analyzed by site year due to the interaction between site year and rye treatment at most of the site years. For each model, rye treatment was considered a fixed factor and block was considered a random factor. LSMEANS statement was used in the model to estimate the least square means. The means were compared with protected Fisher's least significance difference (LSD) at $\alpha=0.10$.

\section{RESULTS}

Winter rye cover crops did not consistently affect most soybean plant parameters tested, although plant population, canopy reflectance, and yield differed significantly among treatments in some site years. Neither soybean shoot and root dry weight between growth stages V2 and V5 (Table 4) nor plant height between V3 and V5 (Table 5) was affected by rye treatments at any location.

\section{Soybean root rot, pathogen incidence, and root characteristics}

Data for root rot severity, root rot incidence, and incidence of detection of Fusarium spp. and Pythium spp. in soybean roots were averaged over all site years with the same rye termination time because there was no interaction between site year and treatment. Root rot severity in the rye treatments ranged from 7 to $29 \%$ and was not influenced by rye treatment. Root rot incidence ranged from 2 to $97 \%$ with no treatment effects (Table 6). The wide range of incidence is because roots with more than $10 \%$ rot severity were considered positive for root rot disease. Similarly, the incidence of Fusarium spp. and Pythium spp. in symptomatic soybean roots ranged from 14 to $22 \%$ and 9 to $13 \%$ of the roots, respectively, and was not influenced by rye cover crop treatment (Table 7). Soybean root growth was similar in all rye treatments, with similar treatment means for root length, area, volume, diameter, and numbers of tips, forks, and crossings (data not shown).

\section{Canopy reflectance}

Canopy reflectance in the no-rye treatment at Boyd Farm was higher than reflectance in the late-kill rye treatment at 80 DAP in $2016(P=0.04)$ but lower at the end of the season in both 2015 and $2016(P \leq 0.001)$ (Fig. 1). At ISUAG, canopy reflectance was not influenced by rye treatments (Fig. 1C).

\section{Soybean plant population}

In 2015, only the late-kill rye treatment at ISUAG resulted in lower soybean plant populations than the no-rye treatment $(P=$ $0.05)$; soybean plant populations were not affected by the early-

\section{TABLE 5}

Mean soybean plant height at vegetative stages (mean \pm standard error) for the no rye, early-kill rye, and late-kill rye treatments at Boyd Farm and Iowa State University Agronomy Farm (ISUAG) in 2015 and 2016

\begin{tabular}{lccr}
\hline & \multicolumn{3}{c}{ Plant height (V3 to V5) } \\
\cline { 2 - 4 } Field site, year & No rye & Early-kill rye $^{\mathrm{a}}$ & Late-kill rye $^{\mathrm{b}}$ \\
\hline Boyd & & & \\
2015 & $3.81 \pm 0.06$ & NA & $4.12 \pm 0.07$ \\
2016 & $1.55 \pm 0.02$ & NA & $1.55 \pm 0.02$ \\
ISUAG & & & \\
2015 & $2.48 \pm 0.06$ & $2.32 \pm 0.06$ & $2.48 \pm 0.06$ \\
2016 & $12.34 \pm 0.06$ & $13.06 \pm 0.06$ & $14.30 \pm 0.06$ \\
\hline
\end{tabular}

${ }^{a}$ Early-kill rye, rye terminated at 34 to 49 days before soybean planting. $\mathrm{NA}=$ Not available, the treatment was not included in the trial.

${ }^{\mathrm{b}}$ Late-kill rye, rye terminated at 5 to 17 days before soybean planting.

TABLE 6

Mean soybean root rot severity and incidence (mean \pm standard error) for the no rye, early-kill rye, and late-kill rye treatments at Gilmore (Agriculture Drainage Water Research Site [ADW]) and the Bradford Research and Extension Center (BREC) in 2012 and 2013, and at Boyd Farm and Iowa State University Agronomy Farm (ISUAG) in 2015 and 2016

\begin{tabular}{|c|c|c|c|c|c|c|c|}
\hline \multirow[b]{2}{*}{ Field site } & \multirow[b]{2}{*}{ Year } & \multicolumn{3}{|c|}{ Root rot severity $(\%)^{\mathrm{a}}$} & \multicolumn{3}{|c|}{ Root rot incidence $(\%)^{\mathrm{b}}$} \\
\hline & & No rye & Early-kill rye $\mathrm{c}^{\mathrm{c}}$ & Late-kill rye ${ }^{\mathrm{d}}$ & No rye & Early-kill rye & Late-kill rye \\
\hline \multirow[t]{2}{*}{ ADW } & 2012 & $16 \pm 0.94$ & NA & $17 \pm 1.21$ & $63 \pm 15.52$ & NA & $63 \pm 14.01$ \\
\hline & 2013 & $7 \pm 0.18$ & NA & $7 \pm 0.29$ & $2 \pm 1.67$ & NA & $3 \pm 3.33$ \\
\hline \multirow[t]{2}{*}{ BREC } & 2012 & $9 \pm 0.60$ & $9 \pm 0.69$ & NA & $22 \pm 5.00$ & $17 \pm 4.30$ & NA \\
\hline & 2013 & $10 \pm 0.93$ & $9 \pm 0.60$ & NA & $27 \pm 24.49$ & $23 \pm 16.89$ & NA \\
\hline \multirow[t]{2}{*}{ Boyd } & 2015 & $13 \pm 0.79$ & NA & $18 \pm 0.87$ & $46 \pm 11.18$ & NA & $65 \pm 4.78$ \\
\hline & 2016 & $21 \pm 0.74$ & NA & $24 \pm 0.95$ & $89 \pm 4.65$ & NA & $92 \pm 4.84$ \\
\hline \multirow[t]{2}{*}{ ISUAG } & 2015 & $20 \pm 1.51$ & $29 \pm 1.14$ & $29 \pm 1.24$ & $97 \pm 1.80$ & $95 \pm 1.56$ & $92 \pm 4.69$ \\
\hline & 2016 & $10 \pm 0.52$ & $13 \pm 0.80$ & $12 \pm 0.72$ & $58 \pm 13.99$ & $47 \pm 17.16$ & $30 \pm 7.05$ \\
\hline
\end{tabular}

${ }^{a}$ Root rot severity was rated on a ratio scale from 0 to $100 \%$ in $1 \%$ intervals, where zero indicates absence of disease. NA = Not available, the treatment was not included in the trial.

${ }^{\mathrm{b}}$ Root rot incidence was the percentage of roots with root rot severity greater than $10 \%$.

${ }^{c}$ Early-kill rye, rye terminated at 34 to 49 days before soybean planting.

${ }^{\mathrm{d}}$ Late-kill rye, terminated at 5 to 17 days before soybean planting. 
kill rye treatment. In 2016, late-kill rye plots had lower plant populations at Boyd Farm $(P=0.006)$; however, both early-kill and late-kill rye plots at ISUAG had marginally higher soybean stand counts than the no-rye control $(P=0.07)$. Soybean populations at $\mathrm{ADW}$ and BREC were not influenced by rye treatment in either year (Table 8).

\section{Soybean yield}

Soybean yield varied among site years, but in most locations and years, rye treatments were not associated with differences in soybean yield (Table 8). In 2016, yield at Boyd Farm was higher in the no-rye treatment than in the late-kill rye treatment $(P=0.03)$. In 2015 , yields in the no-rye plots at ISUAG were greater than yields in the late-kill rye treatment $(P=0.07)$ but not different from yield in plots with early-kill rye. In 2016, the no-rye treatment at ISUAG had lower yields compared with the early- and late-kill rye treatments $(P=0.01)$.

\section{DISCUSSION}

Concerns over possible yield decrease of main crops and increased risk of crop diseases are limiting factors for the use of cover crops (Acharya et al. 2017; Kaspar and Bakker 2015; Singer and Kohler 2005). Planting a rye cover crop before planting corn, for example, can increase corn seedling diseases caused by Fusarium spp. and Pythium spp. and reduce corn emergence, plant population, plant height, and yield (Acharya et al. 2017; Kaspar and Bakker 2015; Singer and Kohler 2005). Fusarium spp. and Pythium spp. cause diseases on roots and seedlings of both soybean and corn (Acharya et al. 2017; Arias et al. 2013b; Broders et al. 2007b). The addition of a rye cover crop in the predominant corn-soybean rotation in the upper Midwest (USDA-NASS 2019) might therefore increase the risk of disease development on soybean. In this study, we investigated whether rye cover crops can contribute to increased risk of soybean root and seedling diseases, poor plant growth, and yield reduction in fields under no-till corn-soybean rotations. Our findings suggest that the use of winter cereal rye cover crops is not detrimental to soybean production. Rye cover crops usually did not reduce soybean yield. They neither enhanced the risk of soybean seedling and root rot diseases nor affected soybean establishment and growth in most of the trial locations.

In our study, rye cover crop had inconsistent effects on soybean grain yield. In 6 of the 8 site years (four locations $\times$ two years), yield was the same or greater in the plots with early- or late-kill rye compared with the plots without rye, whereas in 2 site years, the yield was lower in the plots with late-kill rye compared with the plots without rye. It is common to observe conflicting results regarding the impacts of cover crops on yield of the subsequent soybean crop (Basche et al. 2016; Moore et al. 2014; Reddy 2001). Studies have reported soybean yield increase (Moore et al. 2014, 1994), yield decrease (Eckert 1988; Liebl et al. 1992; Reddy 2001), and no effect (Acharya et al. 2020; Basche et al. 2016; Ruffo et al. 2004; Singer and Kohler 2005) with the use of rye cover crops. In a survey conducted by the Practical Farmers of Iowa (PFI) over 23 site years, soybean yield was seldom affected by rye, except for 6 site years that resulted in yield improvement and 2 site years that had a reduction in yield (Buman et al. 2018). Although we observed a neutral to positive effect of rye on soybean yield in most of the site years in the present study, the inconsistency of impact of a rye cover crop on soybean

TABLE 7

Mean incidence of detection of Fusarium spp. and Pythium spp. in soybean roots (mean \pm standard error) for the no rye, early-kill rye, and late-kill rye treatments at Boyd Farm and Iowa State University Agronomy Farm (ISUAG) in 2015 and 2016

\begin{tabular}{|c|c|c|c|c|c|c|c|}
\hline \multirow[b]{2}{*}{ Field site } & \multirow[b]{2}{*}{ Year } & \multicolumn{3}{|c|}{ Fusarium incidence $(\%)^{\mathrm{a}}$} & \multicolumn{3}{|c|}{ Pythium incidence $(\%)^{\mathrm{a}}$} \\
\hline & & No rye & Early-kill rye ${ }^{b}$ & Late-kill rye ${ }^{c}$ & No rye & Early-kill rye & Late-kill rye \\
\hline \multirow[t]{2}{*}{ Boyd } & 2015 & $16 \pm 1.9$ & NA & $16 \pm 2.2$ & $10.5 \pm 2.3$ & NA & $11.5 \pm 2.0$ \\
\hline & 2016 & $20 \pm 2.1$ & NA & $20 \pm 2.0$ & $13 \pm 1.7$ & NA & $12 \pm 3.0$ \\
\hline \multirow[t]{2}{*}{ ISUAG } & 2015 & $14 \pm 2.0$ & $16.4 \pm 5.3$ & $14.8 \pm 0.8$ & $11.7 \pm 0.8$ & $10.9 \pm 3.0$ & $12.5 \pm 1.3$ \\
\hline & 2016 & $22 \pm 2.2$ & $21.1 \pm 4.7$ & $21.9 \pm 5.3$ & $8.6 \pm 2.3$ & $10.9 \pm 0.9$ & $9.4 \pm 2.9$ \\
\hline
\end{tabular}

${ }^{a}$ Fusarium and Pythium genus were identified morphologically. Incidence was estimated by the number of roots with pathogen presence divided by the total number of root pieces per treatment and multiplied by 100 . NA $=$ Not available, the treatment was not included in the trial.

${ }^{\mathrm{b}}$ Early-kill rye, rye terminated at 34 to 49 days before soybean planting.

${ }^{c}$ Late-kill rye, terminated at 5 to 17 days before soybean planting.

\section{TABLE 8}

Mean soybean plant population and yield (mean \pm standard error) for the no rye, early-kill rye, and late-kill rye treatments at Gilmore (Agriculture Drainage Water Research Site [ADW]) and the Bradford Research and Extension Center (BREC) in 2012 and 2013, and at Boyd Farm and Iowa State University Agronomy Farm (ISUAG) in 2015 and 2016

\begin{tabular}{|c|c|c|c|c|c|c|c|c|}
\hline \multirow[b]{2}{*}{ Field site } & \multirow[b]{2}{*}{ Year } & \multirow[b]{2}{*}{$n$} & \multicolumn{3}{|c|}{ Plant population $\left(1,000\right.$ plants $\left.\cdot \mathrm{ha}^{-1}\right)$} & \multicolumn{3}{|c|}{ Yield $\left(\mathrm{t} \cdot \mathrm{ha}^{-1}\right)$} \\
\hline & & & No rye & Early-kill rye ${ }^{a}$ & Late-kill rye $^{\mathrm{b}}$ & No rye & Early-kill rye & Late-kill rye \\
\hline \multirow[t]{2}{*}{ ADW } & 2012 & 4 & $289 \pm 7.1$ & NA & $260 \pm 12.6$ & $1.82 \pm 0.27$ & NA & $1.86 \pm 0.38$ \\
\hline & 2013 & 4 & $235 \pm 10.6$ & NA & $247 \pm 7.5$ & $2.42 \pm 0.10$ & NA & $2.47 \pm 0.10$ \\
\hline \multirow[t]{2}{*}{ BREC } & 2012 & 4 & $290 \pm 7.4$ & $298 \pm 14.3$ & NA & $2.67 \pm 0.17$ & $2.30 \pm 0.10$ & NA \\
\hline & 2013 & 4 & $\ldots$ & $\ldots$ & NA & $2.06 \pm 0.19$ & $2.00 \pm 0.09$ & NA \\
\hline \multirow[t]{2}{*}{ Boyd } & 2015 & 5 & $404 \pm 11.5$ & NA & $408 \pm 14.7$ & $4.56 \pm 0.06$ & NA & $4.60 \pm 0.06$ \\
\hline & 2016 & 5 & $386 \pm 4.9$ & NA & $346 \pm 9.6$ & $3.75 \pm 0.16$ & NA & $3.40 \pm 0.08$ \\
\hline \multirow[t]{2}{*}{ ISUAG } & 2015 & 4 & $265 \pm 16.0$ & $255 \pm 10.2$ & $205 \pm 19.5$ & $3.26 \pm 0.15$ & $2.98 \pm 0.20$ & $2.83 \pm 0.17$ \\
\hline & 2016 & 4 & $174 \pm 5.0$ & $211 \pm 10.2$ & $204 \pm 13.9$ & $2.04 \pm 0.20$ & $2.51 \pm 0.18$ & $3.00 \pm 0.16$ \\
\hline
\end{tabular}

${ }^{a}$ Early-kill rye, rye terminated at 34 to 49 days before soybean planting. NA $=$ Not available, the treatment was not included in the trial, and ... $=$ data were not collected.

${ }^{b}$ Late-kill rye, rye terminated at 5 to 17 days before soybean planting. 
yield resembles outcomes of previous studies (Basche et al. 2016; Moore et al. 2014; Reddy 2001). This variation in yield of the subsequent crop after a cover crop can be caused by pest and disease pressure, soilborne pathogen density, performance of the crop planter, crop emergence, plant population, plant height, and availability of nutrients and water (Bakker et al. 2016; Buman et al. 2018; Duiker and Curran 2005; Ewing et al. 1991; Liebl et al. 1992; Reddy 2001). Further investigations would be helpful to determine the apparent cause of inconsistent soybean yield response to cover crop.
We found that the use of rye did not affect soybean seedling and root diseases severity caused by Fusarium spp. and Pythium spp. or the incidence of isolation of these pathogens from soybean roots, even though rye is a host of these pathogens (Bakker et al. 2016). Similarly, Acharya et al. (2020) reported no root lesions or very low root rot lesion incidence on soybean following rye. Infected rye has the potential to build up more inoculum in the soil, increasing the risk of disease development (Baker 1971). However, soybean can modify its phenotype in response to biotic and abiotic stress (West-Eberhard 2005), for example,
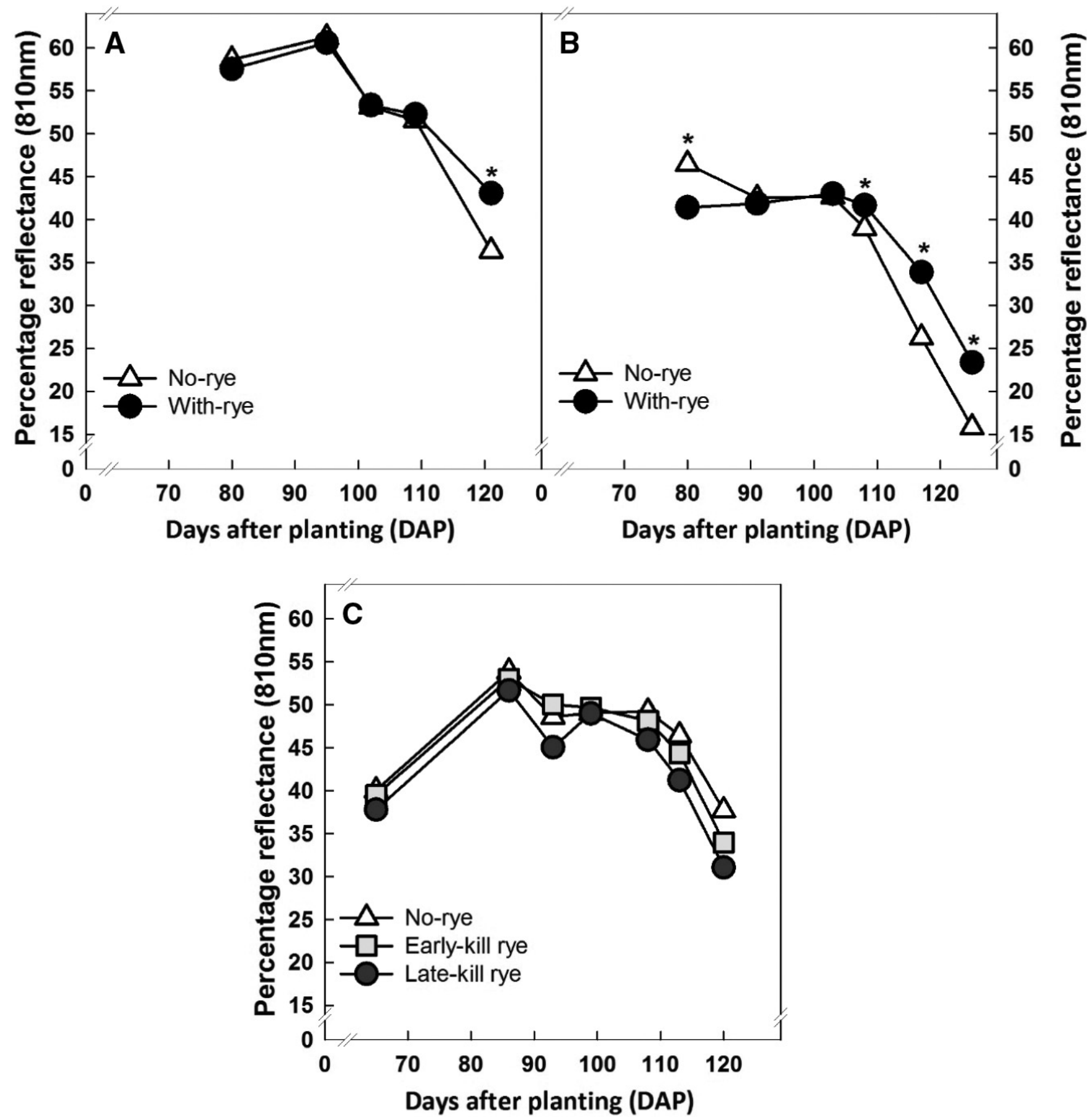

FIGURE 1

Soybean canopy reflectance (\%) at $810 \mathrm{~nm}$ during the growing seasons at Boyd Farm in 2015 (A) and 2016 (B) and at lowa State University Agronomy Farm (ISUAG) in 2015 (C). Among treatments, values marked with an asterisk (*) are statistically different, tested by Fisher's protected least significance difference (LSD) at $\alpha=0.10$. Winter rye cover crop stands were terminated 34 to 49 days before soybean planting (early kill) or 5 to 17 days before soybean planting. 
developing more lateral roots to compensate for the root damage caused by soilborne pathogens. Another possible explanation for the absence of treatment effects is the high levels of soil organic matter and fertility in addition to competing microorganisms in Iowa and Missouri soils, which could have prevented the development of soilborne diseases. Soilborne diseases, such as the ones caused by Fusarium spp. and Pythium spp., are usually more aggressive to plants under low organic matter and fertility, which are compacted and have poor structure and drainage (Abawi and Widmer 2000). There is evidence that high soil organic matter correlates with low disease incidence caused by Pythium spp. (Broders et al. 2009). Although organic matter is a nutrient source for Pythium spp., it also provides an optimal environment for the development of antagonists and competitors, thus creating a competitive environment for Pythium spp. (Broders et al. 2009).

Wen et al. (2017) suggested that when soilborne diseases of soybean are severe, such as Rhizoctonia root rot caused by $R$. solani, rye could lower disease severity and improve yield, but when disease levels are low, rye does not have any effect on disease control or yield. Similarly, Rothrock et al. (1995) observed that the influence of winter legume cover crop on the disease complex of cotton seedlings depended on the prevalent pathogens present in the soil. Our study tested only cereal rye as a cover crop. Other cover crop options being tested in the region, such as winter canola, hairy vetch, and camelina (Appelgate et al. 2017; Schenck et al. 2019), should also be investigated for the effect of soybean diseases. The use of rye as a green manure before a snap bean (Phaseolus vulgaris L.) cash crop has resulted in higher bean yield and lower root rot incited by multiple pathogens (Fusarium solani f. sp. phaseoli, R. solani, P. ultimum, and Thievaliopsis basicola) (Abawi and Widmer 2000).

Another inconsistency observed among the rye treatments in 7 site years of our study was soybean plant population, which was lower in the late-kill rye than in plots without rye in 2 site years, greater in the early-kill rye treatment in 1 site year, and not different in the remaining 4 site years. The reduction in plant population was reflected in lower soybean yield; however, these reductions cannot be attributed directly to seedling or root rot diseases because there were no differences in disease intensity or pathogen incidence among the rye treatments. In 2016, we observed that rye left plentiful biomass on the soil surface, which could have contributed to the low plant population at Boyd Farm because cover crop mulch can act as a physical barrier and prevent light and heat from reaching the soil, thus interfering with crop emergence and growth (Reddy 2001). The large rye biomass probably also interfered with planter operation, affecting seed depth and planter slot closure (Duiker and Curran 2005). Additionally, in 2016, ISUAG had greater plant population in the early-kill rye treatment than in the no-rye treatments. Field observations showed that there was a high weed density in the no-rye plots, which could have competed with soybean for nutrients, water, and light, causing a reduction in plant population and possibly yield (Krausz et al. 2001; Zimdahl 2007). In the future, it might be possible to actively manage the effect of the rye cover crop on soybean population by timing rye termination to prevent too much or too little rye biomass production depending on the weather or weed pressure. Detailed data on cover crop biomass were not collected in this study but would be useful in future studies because cover crop root density and biomass could potentially influence root diseases and overall crop health.

Plant growth parameters such as soybean root morphology, plant biomass, and height can also be indicators of plant health and correlate with yield variation (Agrios 2005; Döring et al. 2012). In our study, soybean root morphology and shoot and root dry weight were not influenced by rye treatments in any of the locations. Even though plant height was not affected by rye treatments, the numerical trend suggests that soybean plants were taller in the rye treatments compared with the plots without rye. Corroborating this observation, Hovermale et al. (1979) showed that soybean plants were taller in high stubble $(35$ to $40 \mathrm{~cm}$ ) compared with low stubble $(10$ to $20 \mathrm{~cm})$. Because of the abundant biomass of rye in rye treatments, competition for light probably caused soybean elongation to occur more rapidly than it did for the plants in the no-rye treatment.

The percentage of soybean canopy reflectance is used to estimate the green leaf area, as a measure of soybean growth and development, and to quantify the effects of disease (Best and Harlan 1985; Guan et al. 2001). Canopy reflectance was assessed as the amount of reflected radiation (800-nm wavelength) of sunlight from green soybean leaves. The lower percentage of reflectance detected at Boyd in the late-kill rye treatment compared with the no-rye treatment in 2016 at 80 DAP was likely a result of the high biomass of rye present in the plots, which could have delayed germination, decreased population, delayed canopy coverage, and reduced soybean vigor (Reddy 2001). The opposite was observed later in the season, as the late-kill rye treatment resulted in a higher percentage of reflectance than the no-rye treatment. The greater canopy reflectance at the end of the season is perhaps due to more green leaves as a result of delayed soybean maturity caused by the slow germination, delayed development, and low plant vigor in the late-kill rye treatment. A delay in physiologic maturation of soybean was also observed by Westgate et al. (2005) when soybean was planted into a high biomass of rye.

The main advantages of including a rye cover crop in soybean production systems are reduced soil erosion and nutrient loss and improved soil health. Our findings suggest that the use of winter rye cover crop does not enhance root diseases in soybean and that the risk of soybean yield loss is low. Although the present study did not predict soybean response under high disease intensity, soybean farmers can benefit from adding a rye cover crop into their agricultural systems to take advantage of the environmental benefits provided by cover crops. Further evaluation of the effects of rye on soybean diseases should be conducted using fields with histories of severe epidemics of soilborne diseases and high soil inoculum levels.

\section{ACKNOWLEDGMENTS}

We thank Stith Wiggs and Sharon Eggenburger for their help in trial management and data collection.

\section{LITERATURE CITED}

Abawi, G., and Widmer, T. 2000. Impact of soil health management practices on soilborne pathogens, nematodes and root diseases of vegetable crops. Appl. Soil Ecol. 15:37-47.

Acharya, J., Bakker, M. G., Moorman, T. B., Kaspar, T. C., Lenssen, A. W., and Robertson, A. E. 2017. Time interval between cover crop termination and planting influences corn seedling disease, plant growth, and yield. Plant Dis. 101:591-600.

Acharya, J., Moorman, T., Kaspar, T., Lenssen, A., and Robertson, A. E. 2020. Cover crop rotation effects on growth and development, seedling disease and yield of corn and soybean. Plant Dis. 104:677-687.

Agrios, G. N. A. 2005. Plant Pathology, 5th ed. Elsevier Academic Press, Burlington, MA.

Allen, T. W., Bradley, C. A., Sisson, A. J., Coker, C. M., Dorrance, A. E., Esker, P. D., Faske, T. R., Giesler, L. J., Hershman, D. E., Hollier, C. A., Jardine, D. J., Kelly, H. M., Kemerait, R. C., Kleczewski, N. M., Kurle, J. E., Malvick, D. K., Markell, S. G., Mehl, H. L., Mueller, D. S., Mueller, J. D., Mulrooney, R. P., Phipps, P. M., Price, P. P., Sikora, E. J., Smith, D. L., Wise, K. A., and Wrather, J. A. 2017. Soybean yield loss estimates 
due to diseases in the United States and Ontario, Canada, from 2010 to 2014. Plant Health Prog. 18:19-27.

Appelgate, S. R., Lenssen, A. W., Wiedenhoeft, M. H., and Kaspar, T. C. 2017. Cover crop options and mixes for upper Midwest corn-soybean systems. Agron. J. 109:968-984.

Arbuckle, J. G., and Roesch-McNally, G. 2015. Cover crop adoption in Iowa: The role of perceived practice characteristics. J. Soil Water Conserv. 70:418-429.

Arias, M. M. D., Leandro, L. F., and Munkvold, G. P. 2013a. Aggressiveness of Fusarium species and impact of root infection on growth and yield of soybeans. Phytopathology 103:822-832.

Arias, M. M. D., Munkvold, G. P., Ellis, M. L., and Leandro, L. F. S. 2013b. Distribution and frequency of Fusarium species associated with soybean roots in Iowa. Plant Dis. 97:1557-1562.

Baker, R. 1971. Analyses involving inoculum density of soil-borne plant pathogens in epidemiology. Phytopathology 61:1280-1292.

Bakker, M. G., Acharya, J., Moorman, T. B., Robertson, A. E., and Kaspar, T. C. 2016. The potential for cereal rye cover crops to host corn seedling pathogens. Phytopathology 106:591-601.

Basche, A. D., Kaspar, T. C., Archontoulis, S. V, Jaynes, D. B., Sauer, T. J., Parkin, T. B., and Miguez, F. E. 2016. Soil water improvements with the long-term use of a winter rye cover crop. Agric. Water Manag. 172: 40-50.

Best, R. G., and Harlan, J. C. 1985. Spectral estimation of green leaf area index of oats. Remote Sens. Environ. 17:27-36.

Bonanomi, G., Antignani, V., Pane, C., and Scala, F. 2007. Suppression of soilborne fungal diseases with organic amendments. J. Plant Pathol. 89: 311-324.

Broders, K. D., Lipps, P. E., Paul, P. A., and Dorrance, A. E. 2007. Characterization of Pythium spp. associated with corn and soybean seed and seedling disease in Ohio. Plant Dis. 91:727-735.

Broders, K. D., Wallhead, M. W., Austin, G. D., Lipps, P. E., Paul, P. A., Mullen, R. W., and Dorrance, A. E. 2009. Ecology and epidemiology association of soil chemical and physical properties with Pythium species diversity, community composition, and disease incidence. Phytopathology 99:957-967.

Buman, B., Caviness, R., Funcke, J., Green, D., Juchems, R., Davis, R., Pierce, D., Pokorny, M., Schaefer, G., Sindt, J., Stout, R., Chester, W., Nelson, D., Dodge, F., Tobin, K., and Market, N. 2018. Winter cereal rye cover crop effect on cash crop yield. https://practicalfarmers.org/research/ winter-cereal-rye-cover-crop-effect-on-cash-crop-yield-4/. Accessed 15 February 2021.

Burkart, M. R., and James, D. E. 1999. Agricultural nitrogen contributions to hypoxia in the Gulf of Mexico. J. Environ. Qual. 28:850-859.

David, M. B., and Gentry, L. E. 2000. Anthropogenic inputs of nitrogen and phosphorus and riverine export for Illinois, USA. J. Environ. Qual. 29:494-508.

Davis, J. R., Huisman, O. C., Everson, D. O., Nolte, P., Sorensen, L. H., and Schneider, A. T. 2010. Ecological relationships of Verticillium wilt suppression of potato by green manures. Am. J. Potato Res. 87: 315-326.

Döring, T. F., Pautasso, M., Finckh, M. R., and Wolfe, M. S. 2012. Concepts of plant health - Reviewing and challenging the foundations of plant protection. Plant Pathol. 61:1-15.

Duiker, S. W., and Curran, W. S. 2005. Rye cover crop management for corn production in the Northern Mid-Atlantic region. Agron. J. 97: 1413-1418.

Eckert, D. J. 1988. Rye cover crops for no-tillage corn and soybean production. J. Prod. Agric. 1:207-210.

Ellis, M. L., Broders, K. D., Paul, P. A., and Dorrance, A. E. 2011. Infection of soybean seed by Fusarium graminearum and effect of seed treatments on disease under controlled conditions. Plant Dis. 95: 401-407.

EPA. 2008. Gulf Hypoxia Action Plan 2008 for Reducing, Mitigating and Controlling Hypoxia in the Northern Gulf of Mexico and Improving Water Quality in the Mississippi River Basin. U.S. Environmental Protection Agency, Washington, D.C., U.S.A.

Ewing, R. P., Wagger, M. G., and Denton, H. P. 1991. Tillage and cover crop management effects on soil water and corn yield. Soil Sci. Soc. Am. J. 55:1081-1085.

FAOSTAT. 2018. FAOSTAT. http://www.fao.org/faostat/en/\#data/QC. Accessed 7 May 2019.

Fehr, W. R., Caviness, C. E., Burmood, D. T., and Pennington, J. S. 1971. Stage of development descriptions for soybeans, Glycine max (L.) Merrill. Crop Sci. 11:929-931.

Galvez, L., Douds, D. D., Wagoner, P., Longnecker, L. R., Drinkwater, L. E., and Janke, R. R. 1995. An overwintering cover crop increases inoculum of VAM fungi in agricultural soil. Am. J. Altern. Agric. 10: $152-156$.
Green, D. E., Burpee, L. L., and Stevenson, K. L. 1998. Canopy reflectance as a measure of disease in tall fescue. Crop Sci. 38:1603-1613.

Guan, J., Nutter, F W, Hall, B., and Nutter, F. W. 2001. Factors that affect the quality and quantity of sunlight reflected from alfalfa canopies. Plant Dis. 85:865-874.

Hovermale, C. H., Camper, H. M., and Alexander, M.W. 1979. Effects of small grain stubble height and mulch on no-tillage soybean production. Agron. J. 71:644-647.

Jeffers, S. N., and Martin, S. B. 1986. Comparison of two media selective for Phytophthora and Pythium species. Plant Dis. 70:1038-1043.

Kaspar, T., and Singer, J. 2011. The use of cover crops to manage soil. Pages 321-337 in: Soil Management: Building a Stable Base for Agriculture. J. Hatfield and T. Sauer, eds. American Society of Agronomy and Soil Science Society of America, Madison, WI.

Kaspar, T. C., and Bakker, M. G. 2015. Biomass production of 12 winter cereal cover crop cultivars and their effect on subsequent no-till corn yield. J. Soil Water Conserv. 70:353-364.

Kaspar, T. C., Jaynes, D. B., Parkin, T. B., and Moorman, T. B. 2007. Rye cover crop and gamagrass strip effects on no concentration and load in tile drainage. J. Environ. Qual. 36:1503-1511.

Komada, H. 1975. Development of a selective medium for quantitative isolation of Fusarium oxysporum from natural soil. Rev. Plant Protect. Res. $8: 114-125$

Korucu, T., Shipitalo, M. J., and Kaspar, T. C. 2018. Rye cover crop increases earthworm populations and reduces losses of broadcast, fall-applied, fertilizers in surface runoff. Soil Tillage Res. 180: 99-106.

Krausz, R. F., Young, B. G., Kapusta, G., and Matthews, J. L. 2001. Influence of weed competition and herbicides on glyphosate-resistant soybean (Glycine max). Weed Technol. 15:530-534.

Larkin, R. P., Griffin, T. S., and Honeycutt, C. W. 2010. Rotation and cover crop effects on soilborne potato diseases, tuber yield, and soil microbial communities. Plant Dis. 94:1491-1502.

Lehman, R. M., Taheri, W. I., Osborne, S. L., Buyer, J. S., and Douds, D. D. 2012. Fall cover cropping can increase arbuscular mycorrhizae in soils supporting intensive agricultural production. Appl. Soil Ecol. 61: 300-304.

Liebl, R., Simmons, F., and Wax, L. 1992. Effect of rye (Secale cereale) mulch on weed control and soil moisture in soybean (Glycine max). Weed Technol. 6:838-846.

Lu, Y.-C., Watkins, K. B., Teasdale, J. R., and Abdul-baki, A. A 2000. Cover crops in sustainable food production. Food Rev. Int. 16: 121-157.

Moore, E. B., Wiedenhoeft, M. H., Kaspar, T. C., and Cambardella, C. A. 2014. Rye cover crop effects on soil quality in no-till corn silage-soybean cropping systems. Soil Sci. Soc. Am. J. 78:968-976.

Moore, M. J., Gillespie, T. J., Swanton, C. J., and Swanton, C. J. 1994. Effect of cover crop mulches on weed emergence, weed biomass, and soybean (Glycine max) development.. Weed Technol. 8:512-518.

Nelson, P. E., Toussoun, T. A., and Marasas, W. F. O. 1983. Fusarium Species: An Illustrated Manual for Identification. Pennsylvania State University Press, University Park, PA, U.S.A.

Nitta, T. 1991. Diversity of root fungal floras: Its implications for soil-borne diseases and crop growth. Japan Agric. Res. Q. 25:6-11.

Nutter, F. W., Tylka, G. L., Guan, J., Moreira, A. J. D., and Marett, C. C. 2002. Use of remote sensing to detect soybean cyst nematode-induced plant stress. J. Nematol. 34:222-231.

Pimentel, D., Harvey, C., Resosudarmo, P., Sinclair, K., Kurz, D., Mcnair, M., Crist, S., Shpritz, L., Fitton, L., Saffouri, R., and Blair, R. 1995. Environmental and economic costs of soil erosion and conservation benefits. Science 267:1117-1123.

Pitt, J. I., and Miller, M. W. 1968. Sporulation in Candida pulcherrima, Candida reukaufii and Chlamydozyma species: Their relationships with Metschnikowia. Mycologia 60:663-685.

Qi, Z., and Helmers, M. J. 2010. Soil water dynamics under winter rye cover crop in central Iowa. Vadose Zo. J. 9:53-60.

Reddy, K. N. 2001. Effects of cereal and legume cover crop residues on weeds, yield, and net return in soybean (Glycine max). Weed Technol. 15:660-668.

Rothrock, C. S., Kirkpatrick, T. L., Frans, R. E., and Scott, H. D. 1995. The influence of winter legume cover crops on soilborne plant pathogens and cotton seedling diseases. Plant Dis. 79:167-171.

Ruffo, M. L., Bullock, D. G., and Bollero, G. A. 2004. Soybean yield as affected by biomass and nitrogen uptake of cereal rye in winter cover crop rotations. Agron. J. 96:800-804.

Rupe, J. C. C., Robbins, R. T. T., and Gbur, E. E. E. 1997. Effect of crop rotation on soil population densities of Fusarium solani and Heterodera glycines and on the development of sudden death syndrome of soybean. Crop Prot. 16:575-580. 
Sarrantonio, M., and Gallandt, E. 2003. The role of cover crops in North American cropping systems. J. Crop Prod. 8:53-74.

Schenck, L. A., Bakker, M. G., Moorman, T. B., and Kaspar, T. C. 2019. Effects of cover crop presence, cover crop species selection and fungicide seed treatment on corn seedling growth. Renew. Agric. Food Syst. 34: 93-102.

Singer, J. W., and Kohler, K. A. 2005. Rye cover crop management affects grain yield in a soybean-corn rotation. Crop Manag. 4:20-25.

Singer, J. W., Nusser, S. M., and Alf, C. J. 2007. Are cover crops being used in the US corn belt? J. Soil Water Conserv. 62:353-358.

Snapp, S., Nyiraneza, J., and O’Neil, K. 2002. Improving Productivity and Soil Quality in Short Potato Rotations. Michigan Potato Research Report. East Lansing, MI.

USDA-NASS. 2019. Quick Stats. Washington, DC.

Van der Plaats-Niterink, A. 1981. Monograph of the genus Pythium. Stud. Micol. 21:1-242.
Van Os, G. J., and Van Ginkel, J. H. 2001. Suppression of Pythium root rot in bulbous Iris in relation to biomass and activity of the soil microflora. Soil Biol. Biochem. 33:1447-1454.

Villamil, M. B., Bollero, G. A., Darmody, R. G., Simmons, F. W., and Bullock, D. G. 2006. No-till corn/soybean systems including winter cover crops. Soil Sci. Soc. Am. J. 70:1936.

Wen, L., Lee-Marzano, S., Ortiz-Ribbing, L. M., Gruver, J., Hartman, G. L., and Eastburn, D. M. 2017. Suppression of soilborne diseases of soybean with cover crops. Plant Dis. 101:1918-1928.

West-Eberhard, M. J. 2005. Developmental plasticity and the origin of species differences. Proc. Natl. Acad. Sci. 102:6543-6549.

Westgate, L. R., Singer, J. W., and Kohler, K. A. 2005. Method and timing of rye control affects soybean development and resource utilization. Agron. J. 97:806-816.

Zimdahl, R. L. 2007. Fundamentals of Weed Science, 3rd ed. Elsevier Academic Press, San Diego, CA. 